\title{
Provenance connections between late Neoproterozoic and early Palaeozoic sedimentary basins of the Ross Sea region, Antarctica, south-east Australia and southern Zealandia
}

\author{
C.J. ADAMS ${ }^{1}$, J.D. BRADSHAW ${ }^{2}$ and T.R. IRELAND ${ }^{3}$ \\ ${ }^{1}$ GNS Science, Private Bag 1930, Dunedin 9054, New Zealand \\ ${ }^{2}$ Department of Earth Sciences, Canterbury University, Zealand, Christchurch, New Zealand \\ ${ }^{3}$ Research School of Earth Sciences, The Australian National University, Canberra, ACT 0200, Australia \\ argon@gns.cri.nz
}

\begin{abstract}
Thick successions of turbidites are widespread in the Ross-Delamerian and Lachlan orogens and are now dispersed through Australia, Antarctica and New Zealand. U-Pb detrital zircon age patterns for latest Precambrian, Cambrian and Ordovician metagreywackes show a closely related provenance. The latest Neoproterozoic-early Palaeozoic sedimentary rocks have major components, at $c .525,550$, and $595 \mathrm{Ma}$, i.e. about 40-80 million years older than deposition. Zircons in these components increase from the Neoproterozoic to Ordovician. Late Mesoproterozoic age components, 1030 and $1070 \mathrm{Ma}$, probably originate from igneous/metamorphic rocks in the Gondwanaland hinterland whose exact locations are unknown. Although small, the youngest zircon age components are coincident with estimated depositional ages suggesting that they reflect contemporaneous and minor, volcanic sources. Overall, the detrital zircon provenance patterns reflect the development of plutonic/metamorphic complexes of the Ross-Delamerian Orogen in the Transantarctic Mountains and southern Australia that, upon exhumation, supplied sediment to regional scale basin(s) at the Gondwana margin. Tasmanian detrital zircon age patterns differ from those seen in intra-Ross Orogen sandstones of northern Victoria Land and from the oldest metasediments in the Transantarctic Mountains. A comparison with rocks from the latter supports an allochthonous western Tasmania model and amalgamation with Australia in late Cambrian time.
\end{abstract}

Received 16 December 2012, accepted 29 April 2013

Key words: detrital zircon geochronology, Marie Byrd Land, New Zealand, northern Victoria Land, provenance studies, Tasmania

\section{Introduction}

Late Precambrian-early Palaeozoic, greywacke-dominated turbidite successions are a widespread and volumetrically significant feature of the eastern margin of the Gondwana supercontinent (Fig. 1). They occupy extensive areas $\left(>100000 \mathrm{~km}^{2}\right.$ scale) bordering the Precambrian cratons of East Antarctica and Australia. An inboard turbidite sector forms the western part of northern Victoria Land and lies within the Ross Orogen of East Antarctica and its continuation as the Delamerian Orogen in South Australia. The Cambrian rocks of the Bowers Terrane (Antarctica) and Takaka Terrane (New Zealand) are remnants of accreted arc to back-arc successions (Bradshaw et al. 2009). An outboard sector comprises the Lachlan Orogen of southeastern Australia (Glen 2005), and its continuations into northern Victoria Land and Marie Byrd Land (Antarctica), and in South Island, New Zealand, a foreland, Western Province (Pankhurst et al. 1998, Adams 2007, Bradshaw et al. 2009). The regional monotony of lithology and structural complexity allow very limited lithostratigraphic subdivision except in parts of south-east Australia and north-west Nelson, South Island, New Zealand, where graptolites are locally common. Elsewhere, rare fossil occurrences are usually confined to single localities, tectonically isolated enclaves or allochthonous blocks.

The inboard turbidite successions (Fig. 1) occur within the Ross-Delamerian Orogen and are typically affected by Cambrian deformation and metamorphism and may be cut by Ross-Delamerian granites. Sedimentary rocks of the outboard group (Fig. 1) were deposited at a continental margin during and after the Ross-Delamerian Orogeny and show deformation and metamorphism at c. $440 \mathrm{Ma}$, the Benambran Orogeny of Australia (Glen 2005 and references therein). Between these, in the Bowers Terrane of northern Victoria Land and Takaka Terrane of New Zealand (Fig. 1), there was development of shallower-water successions with adjacent volcanic arcs (Bradshaw et al. 2009). On a reconstruction of East Gondwana (Fig. 1) most of the turbidites in both groups occur adjacent to the Mesoproterozoic-Neoproterozoic margin of AustraliaAntarctica.

$\mathrm{K}-\mathrm{Ar}, \mathrm{Ar}-\mathrm{Ar}$ and $\mathrm{Rb}-\mathrm{Sr}$ metamorphic ages of slates in northern Victoria Land (Adams \& Kreuzer 1984, 


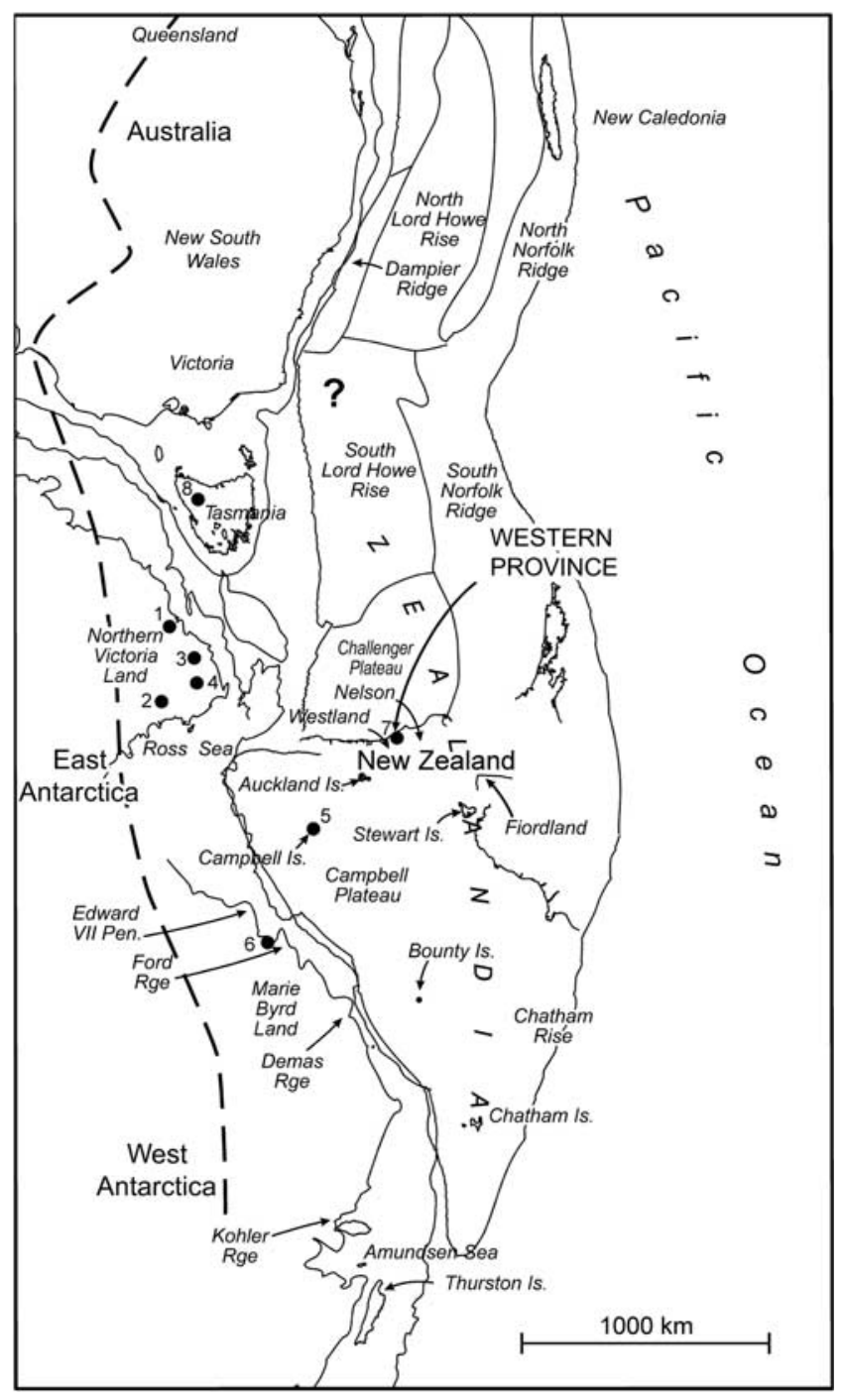

Fig. 1. Late Palaeozoic reconstruction of Pacific margin of East Gondwana (after Sutherland 1999) showing the late Precambrian continental margin (dashed line) and the probable extent of the latest late Neoproterozoic-Ordovician sedimentary successions (grey), and their probable continuations (pale grey), of the Lachlan Fold Belt, south-east Australia, and equivalents in northern Victoria Land (Wilson, Bowers and Robertson Bay terranes) and Marie Byrd Land, Antarctica, and Zealandia (Buller and Takaka terranes, Western Province, New Zealand). Dots indicate sample localities discussed in text: $1=$ Berg Mountains, Oates Coast, 2 = Priestley Glacier, Terra Nova Bay (Wilson Terrane), $3=$ Edlin Névé (Bowers Terrane), $4=$ Millen Range (Robertson Bay Terrane), $5=$ Swanson Mountains, Ford Ranges, $6=$ Complex Point, Campbell Island, $7=$ Ross, Westland, New Zealand, $8=$ Tyennan block, Tasmania.

Dallmeyer \& Wright 1992) constrain minimum depositional ages of the main greywacke successions although, in some cases, individual ages appear to be too old. Three main metamorphic phases are indicated: latest Neoproterozoic, middle-late Cambrian, and Late Ordovician-early Silurian.

In order to explore the geodynamic development of the region and to constrain maximum depositional ages and provenance of its sedimentary rocks, we report here $\mathrm{U}-\mathrm{Pb}$ detrital zircon ages of latest Neoproterozoic, Cambrian and Ordovician greywackes from the Ross Sea region (including the southern New Zealand region). Geochronological data from eastern Australia and Tasmania have recently been published and reviewed by Fergusson (2009) and Berry et al. (2007). These extend previous studies in south-east Australia, Antarctica and New Zealand (Ireland \& Gibson 1998, Ireland et al. 1998) which show uniform detrital zircon age patterns that reflect episodic uplift and erosion within the Ross-Delamerian Orogen itself, and a persistent contribution from more stable Palaeo- and Mesoproterozoic cratonic sources (Ireland et al. 1998). The latest Cambrian to Ordovician sandstones of the Lachlan Orogen thus contain a major zircon component from active erosion of the Ross-Delamerian Orogen.

\section{Outline of late Precambrian-early Palaeozoic geology}

Northern Victoria Land, East Antarctica

The Cambrian-Ordovician, Ross Orogen forms the basement of the Transantarctic Mountains along the eastern edge of the East Antarctic craton (Fig. 1) (Stump 1995). At the Pacific Ocean termination of the mountains, in northern Victoria Land (NVL), three terranes are recognized: a broad, western Wilson Terrane, a narrow central Bowers Terrane orientated north-west/south-east and a broad eastern Robertson Bay Terrane. The Wilson Terrane contains greenschist facies metasediments (Berg Group, Priestley Formation and Priestley Schist), greenschist to amphibolite facies orthogneiss (Wilson Gneiss) and paragneiss (Rennick Schist), and voluminous late Cambrian-earliest Ordovician granitoid complexes (Granite Harbour Intrusives) which represent an active Cambrian continental margin arc. The Bowers Terrane is a diverse slice of oceanic arc or back-arc volcanic and sedimentary rocks (Fig. 1), the latter with mixed arc and continental provenances. The Robertson Bay Terrane likewise contains predominant, latest Cambrian to Ordovician, greenschist facies, turbiditic metasediments (Robertson Bay Group - see comprehensive references cited in Stump 1995). The Wilson and Bowers terranes show Cambrian deformation and metamorphism typical of the Ross-Delamerian Orogeny. Deformation of the Robertson Bay Terrane appears younger (Late Ordovician-Silurian) and is best regarded as part of the Lachlan Orogen (Bradshaw 2007).

\section{Marie Byrd Land, West Antarctica}

The early Palaeozoic, low-grade metasedimentary, Swanson Formation is widespread in western Marie Byrd Land as 
Table I. Sample details for Precambrian-early Palaeozoic metasediments: Antarctica, Zealandia, Australia.

\begin{tabular}{|c|c|c|c|c|}
\hline $\begin{array}{l}\text { Locality } \\
\text { no. }\end{array}$ & $\begin{array}{l}\text { Sample } \\
\text { acronym }\end{array}$ & $\begin{array}{l}\text { Stratigraphic unit } \\
\text { (and estimated age, where known) }\end{array}$ & Location & Longitude, latitude \\
\hline \multicolumn{5}{|c|}{ North Victoria Land, East Antarctica } \\
\hline 2 & R14855/FO60 & Priestley Formation, Precambrian & Foolsmate Glacier, Priestley Glacier & $161^{\circ} 57^{\prime} \mathrm{E}, 74^{\circ} 05^{\prime} \mathrm{S}$ \\
\hline 3 & $81 / 105$ & Molar Formation, ?middle Cambrian & Edlin Névé, Bowers Mountains & $162^{\circ} 55^{\prime} \mathrm{E}, 71^{\circ} 07^{\prime} \mathrm{S}$ \\
\hline 4 & $84 / 12$ & Robertson Bay Group, Ordovician & East Handler Ridge, Millen Range, Evans Névé & $167^{\circ} 08^{\prime} \mathrm{E}, 72^{\circ} 30^{\prime} \mathrm{S}$ \\
\hline \multicolumn{5}{|l|}{ Zealandia } \\
\hline 6 & R14202/CAM11 & Complex Point Formation & Complex Point, Campbell Island & $149^{\circ} 05^{\prime} \mathrm{W}, 52^{\circ} 32^{\prime} \mathrm{S}$ \\
\hline 7 & R15432/GE1 & Greenland Group, Ordovician & Jones Track, Ross, Westland, NZ & $\mathrm{J} 33 / 304083^{1}$ \\
\hline \multicolumn{5}{|c|}{ Tasmania, Australia } \\
\hline 8 & R6533/MCPP1 & Tyennan Block, Precambrian & McPartlands Pass, western Tasmania & DN335549 ${ }^{2}$ \\
\hline
\end{tabular}

${ }^{1} \mathrm{NZ}$ metric NZMS260 grid reference.

${ }^{2}$ Australian AMG co-ordinates.

thick unfossiliferous successions of quartzose turbidites (Bradshaw et al. 1983). K-Ar and Rb-Sr cooling ages indicate the oldest metamorphism is early Silurian, c. 430-440 Ma. The Swanson Formation is similar to the Robertson Bay Group (NVL) and Greenland Group of South Island, New Zealand (Bradshaw et al. 1983, Adams 2004).

\section{Southern Zealandia}

In New Zealand and the adjoining continental submarine plateaux (together termed Zealandia), the oldest basement rocks (Western Province, Fig. 1) are within early Palaeozoic, Buller and Takaka terranes (Cooper 1989). The Buller Terrane is divided by the Devonian, Karamea Batholith into an eastern section with graptolitic, Early-Middle Ordovician successions, and a western section with extensive, Greenland Group metasediments (Cooper 1989). The latter are proximal to mid-fan turbidites with a single Early Ordovician (Lancefieldian) graptolite locality (Cooper 1974) whose earliest metamorphism is Late Ordovician-early Silurian, c. $440 \mathrm{Ma}$ (Adams 2004 and references therein). Geochemical signatures indicate a dominantly granitoid source (Roser et al. 1996). Detrital zircon ages (Ireland \& Gibson 1998) have major age components in latest Cambrian-Early Ordovician (505-470 Ma) and late Neoproterozoic-Cambrian (650-530 Ma) ranges. A significant, but smaller, late Mesoproterozoic-early Neoproterozoic (1200-900 Ma) detrital zircon component is also present.

In southernmost Zealandia, on Campbell Island, a tiny area $\left(<1 \mathrm{~km}^{2}\right)$ of early Palaeozoic schist, the Complex Point Formation, provides evidence for a connection between the Australasian and Antarctic sectors. The formation is probably composite, with two sectors having respectively early Cambrian and Early Ordovician metamorphism (Adams 2007).

\section{Tasmania}

Tasmania differs from the other areas considered here, having Precambrian rocks, which pre-date Rodinia break-up at c. $750 \mathrm{Ma}$. In the late Neoproterozoic-early Cambrian, Tasmania was part of a Gondwana passive margin. This situation that was abruptly changed in early middle Cambrian time by the emplacement of mafic volcanic allochthons driven by plate convergence. The emplacement of the allochthons at c. $510 \mathrm{Ma}$ (Berry et al. 2007) was followed by extension, with eruption of late Cambrian, Mount Read Volcanics and, finally, latest Cambrian conglomerate and quartzite and Ordovician carbonate-rich successions. However, in eastern Tasmania, the Ordovician is represented by graptolitic turbidites.

The Cambrian tectonic and magmatic events in western Tasmania and the New Zealand Takaka Terrane are clearly different, but the sedimentary styles through Ordovician to Early Devonian time are similar. Both differ from the post-Cambrian rocks of the Bowers Terrane.

\section{Technical details}

The samples analysed are low- to medium-grade metasedimentary rocks (mainly greenschist facies), originally coarse sandstone, greywacke or quartzite. Detrital zircons were extracted from $1-2 \mathrm{~kg}$ samples by conventional magnetic and specific gravity separation techniques. $\mathrm{U}-\mathrm{Pb}$ zircon ages were determined in the SHRIMP laboratory, Research School of Earth Sciences, Australian National University, Canberra, following procedures outlined in Ireland et al. (1998). U-Pb age data were obtained for eight samples from localities shown in Fig. 1 and details listed in Table I: East Antarctica (localities 1-4), West Antarctica (5), Zealandia $(6,7)$, and Tasmania (8). The U-Pb ages are listed in Table S1 (which will be found at http://dx.doi.org/10.1017/ S0954102013000461) where those $<1000 \mathrm{Ma}$ are ${ }^{206} \mathrm{~Pb} /{ }^{238} \mathrm{U}$ ages, and $>1000 \mathrm{Ma}$ are ${ }^{207} \mathrm{~Pb} /{ }^{206} \mathrm{~Pb}$ ages. 

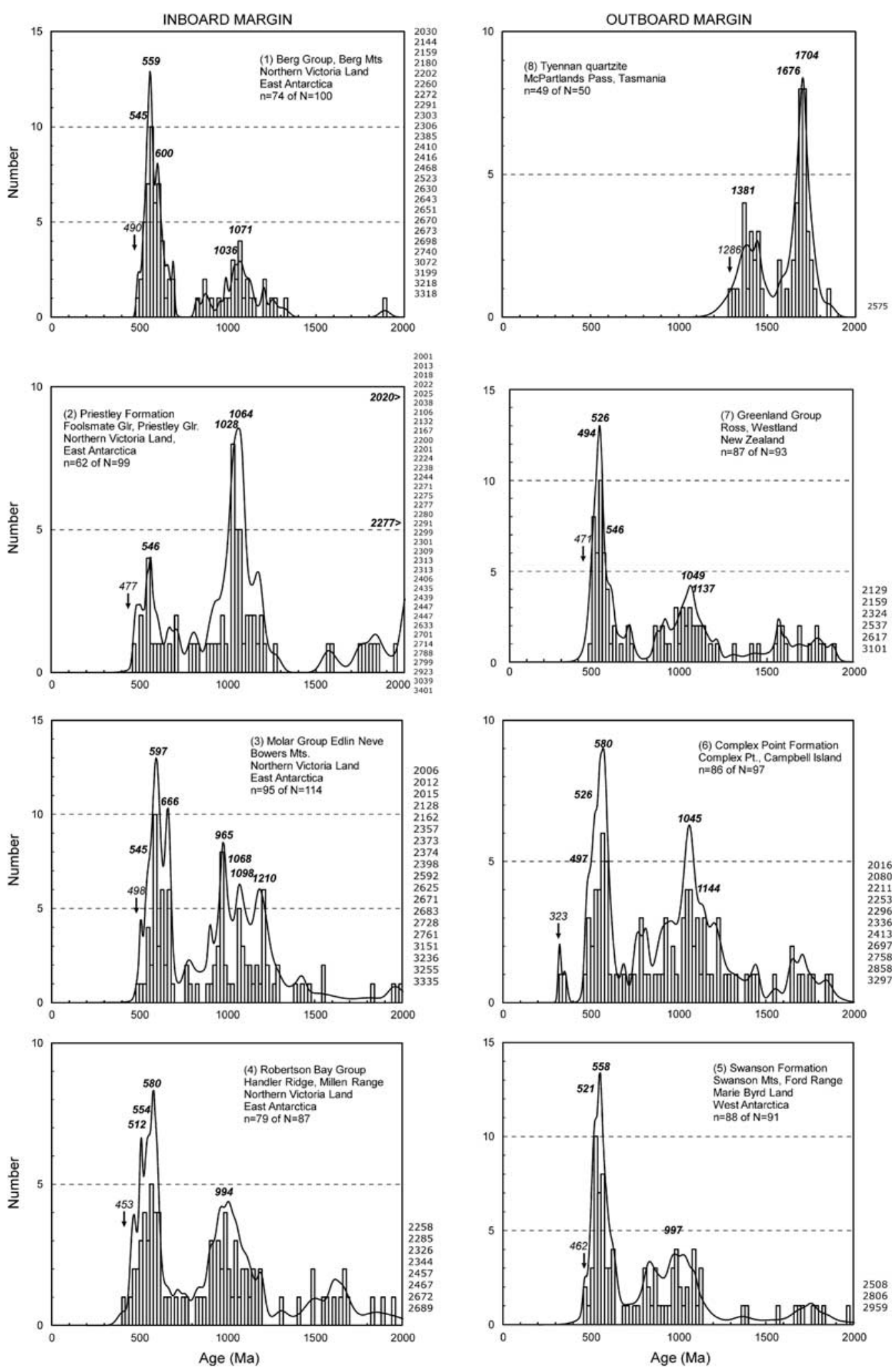

Fig. 2. Combined probability density and histogram diagram for detrital zircon ages from latest Neoproterozoic-Ordovician metagreywackes in Antarctica, Zealandia and Australia. Datasets shown in the right and left columns are respectively from inboard and outboard turbidite localities. Locality numbers are from Table I. Ages $<1000 \mathrm{Ma}$ are ${ }^{206} \mathrm{~Pb} /{ }^{238} \mathrm{U}$ analyses, ages $>1000 \mathrm{Ma}$ are ${ }^{207} \mathrm{~Pb} /{ }^{206} \mathrm{~Pb}$ analyses. Ages $>2000 \mathrm{Ma}$ are stacked at the right margin. The ages of significant age components (Table S1, which will be found at http://dx.doi.org/10.1017/S0954102013000461) are shown in bold italics. In each case, the youngest individual mineral age is shown in italics and marked by an arrow. 
Full $\mathrm{U}, \mathrm{Th}, \mathrm{Pb}$ isotopic ratio data and calculated and corrected $\mathrm{U}-\mathrm{Pb}$ ages are available in Table S2, which will be found at http://dx.doi.org/10.1017/S0954102013000461. Combined histogram and probability density curves (Fig. 2) were created from these datasets using ISOPLOT 3.0 software (K. Ludwig, United States Geological Survey). From the probability density curves, statistically-significant age components (and their errors) are recognized as those groups of zircon ages with at least four analyses whose ${ }^{206} \mathrm{~Pb} /{ }^{238} \mathrm{U}$ and ${ }^{207} \mathrm{~Pb} /{ }^{235} \mathrm{U}$ ages coincide at $95 \%$ confidence limits, and also comprise $>4 \%$ of total set. These component ages and their proportions (as \% of the total dataset) are listed in the right-hand columns of Table S1, which will be found at http://dx.doi.org/10.1017/S0954102013000461).

\section{Results}

With the exception of Tasmanian sample 8, a common feature of the detrital zircon age results is the presence of two principal age groups (Fig. 2): late Neoproterozoic-Early Ordovician (700-470 Ma) and late Mesoproterozoic-early Neoproterozoic (1200-900 Ma). From the older samples $(2,3)$ to the younger ones $(4,5,6,7)$, the proportion of the younger group increases at the expense of the older. In addition, all samples carry a rather variable proportion of Palaeoproterozoic and Archean (to 3400 Ma) ages without any consistent grouping. These older ages are an important feature (33\%) of the late Neoproterozoic-Cambrian samples $(1,2,3)$ and decline $($ to $<5 \%)$ in the late Cambrian-Ordovician samples $(4,5,6,7)$. The Tyennan sample (8) is radically different. It has neither of the above age groups but rather, has early Mesoproterozoic (1500-1300 Ma) and late Palaeoproterozoic (1800-1600 Ma) age groups. In all cases, the most robust estimate of the maximum depositional age is given by that of the youngest statistically-significant age component. In some cases, the few individual ages younger than this (samples 2, 4, 6) should be treated with caution as they may reflect partial or whole $\mathrm{Pb}$ loss during the widespread Ordovician metamorphism. However, these youngest ages are also noted in Fig. 2.

\section{Detrital zircon age patterns}

The detrital zircon age diagrams are organized by locality number in Fig. 2: those in the left column are 'inboard', Gondwanaland samples from northern Victoria Land, and those in the right column are the 'outboard' samples from Marie Byrd Land, Zealandia and south-east Australia.

\section{Wilson Terrane, northern Victoria Land}

Detrital zircon age patterns for metagreywackes at localities in the Berg Mountains, Oates Coast (1), and in Foolsmate Glacier, tributary to Priestley Glacier, Terra Nova Bay (2), show a pattern seen in most late Precambrian and early Palaeozoic samples in the Delamerian and Lachlan orogens of south-east Australia (and correlates in Zealandia), with two major groups (always $>10 \%$, and often $>33 \%$ of total) in latest Proterozoic-Cambrian, 500-700 Ma, and late Mesoproterozoic, 1000-1250 Ma, age ranges (Fig. 2). Only few zircons are in the range 1300-2000 Ma. However, both samples represent an extreme situation, having $>25 \%$ of zircons (otherwise usually $<10 \%$ ) with ages $>2000 \mathrm{Ma}$.

In the Berg Mountains sample (1), the youngest statistically-significant component age, $545 \pm 11 \mathrm{Ma}$, sets a maximum, latest Neoproterozoic-early Cambrian, depositional age for the Berg Group, whilst its $\mathrm{Rb}-\mathrm{Sr}$ metamorphic age, $515 \pm 6 \mathrm{Ma}$ (Adams 1996), sets a late middle Cambrian minimum. A single zircon age, $490 \pm 8 \mathrm{Ma}$, is younger than this and presumably has undergone some $\mathrm{Pb}$ loss during metamorphism.

The Foolsmate (Priestley) Glacier sample (2) has a similar youngest zircon component age, $546 \pm 16 \mathrm{Ma}$, and $\mathrm{Rb}$-Sr metamorphic age, $512 \pm 9 \mathrm{Ma}$ (Adams 1997), thus the indicated depositional age constraints for the Priestley Formation are the same as the Berg Group (above). Significantly, this sample also has the highest proportion $(37 \%)$ of zircons $>2000 \mathrm{Ma}$, and unusually high ratio of Mesoproterozoic/late Neoproterozoic-Cambrian zircons, $>3$ (which is more normally $<1$ ). This suggests that the Foolsmate Glacier succession represents an early Cambrian (or possibly latest Neoproterozoic) stage of Priestley Formation deposition, at a time when the sediment provenance was still dominated by Precambrian sources $>1000 \mathrm{Ma}$, but the Berg Mountains sample is from slightly younger successions that now had sediment provenances that included rapidly-developing and freshly-exhumed latest Neoproterozoic-early Cambrian sources. An interesting point here is that the younger $\mathrm{Rb}-\mathrm{Sr}$ metamorphic ages correspond closely to the metamorphic ages, 515-505 Ma, reported in Tasmania (Berry et al. 2007), where they reflect a major, Delamerian tectonic event. Thus, the turbidite sedimentary basins within the Wilson Terrane are probably mainly late Neoproterozoic in age and predate this tectonic phase.

\section{Bowers Terrane, northern Victoria Land}

The Bowers Terrane sample (3) collected at Edlin Névé comes from the younger part of the Molar Formation (late middle Cambrian). These sediments originated in part from the Wilson Terrane granitoid complexes at an active continental margin (Henjes-Kunst \& Schussler 2003). The detrital zircon age patterns (Fig. 2) continue the trend observed in the Berg and Priestley Glacier samples (above), namely, the diminishment of Archean-early Proterozoic zircons, $>2000 \mathrm{Ma}$ (now $<15 \%$ ), and Mesoproterozoic zircons, $1000-1250 \mathrm{Ma}$ (now $<20 \%$ ), at the expense of latest Neoproterozoic-early Cambrian components $(>30 \%)$, 
now with a dominant, youngest component at $545 \pm 16 \mathrm{Ma}$. This situation is similar to that in the transition from passive- to active-margin sedimentation as reflected in late Neoproterozoic-early Palaeozoic sedimentary rocks of the Central Transantarctic Mountains (Goodge et al. 2002, 2004). A younger, $515 \mathrm{Ma}$, granite clast has been reported from the Molar Formation in the Carryer Glacier (Weaver, personal communication 2003). All the ages are thus consistent with its accepted middle Cambrian age.

\section{Robertson Bay Terrane}

The Robertson Bay Terrane sample from locality 4 is close to the only fossil occurrence in the terrane, at Handler Ridge, Millen Range, where a series of allochthonous limestone blocks of probable latest Cambrian-Early Ordovician age lie within a thick pebbly mass flow deposit. This fossiliferous, Handler Formation was originally interpreted as the youngest part of the Robertson Bay Group but it now appears possible that it is, in fact, the oldest part of a mainly Ordovician succession (Bradshaw 2007). The youngest, statistically-significant zircon age component, $512 \pm 12 \mathrm{Ma}$, is older than the depositional age (c. $490 \mathrm{Ma}$ ) of the limestone blocks nearby. However, there are in addition rather scattered individual zircon ages in the range 408-491 Ma, whose reliability is far less uncertain. It is probable that the main Robertson Bay Group turbidites, including the sample at locality 4, are younger than the Handler Formation. The continued reduction in the proportion of zircon ages $>2000 \mathrm{Ma}$ (now $<10 \%$ ) and decrease in the proportion of Mesoproterozoic/late Neoproterozoic-Cambrian zircons (now $<0.7$ ), resembles the pattern of the probable Ordovician greywacke at locality 7 in New Zealand.

\section{Marie Byrd Land}

The Swanson Formation, widespread in western Marie Byrd Land, resembles the Robertson Bay Group in structure, sedimentological style, and $\mathrm{K}-\mathrm{Ar}$ and $\mathrm{Rb}-\mathrm{Sr}$ geochronology (Bradshaw et al. 1983). In this respect, the sample from Swanson Mountains locality 5 has a pattern similar to locality 4: zircons $>2000 \mathrm{Ma}$ are now trivial, the proportion of Mesoproterozoic/late Neoproterozoic-Cambrian zircons declines to 0.3 , and the youngest age component in the latter, $521 \pm 4 \mathrm{Ma}$, is now part of a very dominant $(>40 \%)$ age group. This indicates a maximum, middle Cambrian, depositional age for the Swanson Formation.

\section{Zealandia}

As noted earlier, the Complex Point Formation on the sub-Antarctic Campbell Island is probably composite. At Complex Point, the schists and slates yield Late Ordovician, c. $440 \mathrm{Ma}$, K-Ar and Rb-Sr metamorphic ages (Adams 2007).
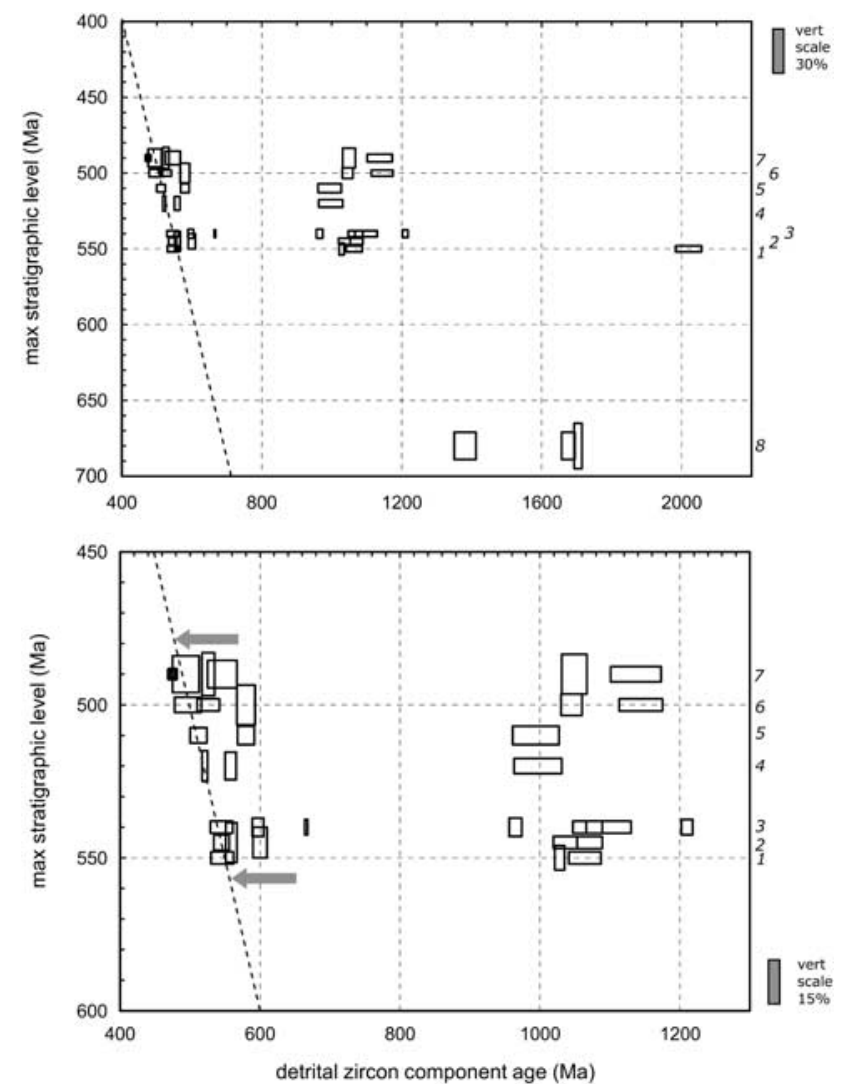

Fig. 3. Detrital zircon $\mathrm{U}-\mathrm{Pb}$ age components in latest Neoproterozoic, Cambrian and Ordovician greywackes at the East Gondwana continental margin. The upper diagram represents the full dataset, $400-2200 \mathrm{Ma}$, the lower diagram is an enlargement of the 400-1300 Ma sector. Component age peaks are calculated from probability density curves (Fig. 2 and Table S1, which will be found at http://dx.doi.org/ $10.1017 / \mathrm{S} 0954102013000461)$ of ${ }^{206} \mathrm{~Pb} /{ }^{238} \mathrm{U}$ ages where $<1000 \mathrm{Ma}$, and of ${ }^{207} \mathrm{~Pb} /{ }^{206} \mathrm{~Pb}$ ages where $>1000 \mathrm{Ma}$. Error box widths are the component age error at $95 \%$ confidence limits, and the error-box heights represent the proportion of that component as a percentage of the total (see a reference scale bar at right). Age data are stacked from top to bottom on the vertical axis in ascending order of their youngest component age. The small heavy box in locality 7 data represents its estimated stratigraphic age. The Tyennan data (8) are arbitrarily placed at the bottom of the upper diagram. The dashed line is the stratigraphic limit, which ideally forms the younger age boundary to the detrital zircon age data. The pale grey solid arrows schematically highlight a diachronous trend in the younger zircon age groups. The sample locality numbers (italics) (Table I) are shown at the right margin.

Metagreywacke at this locality 6 has a detrital zircon age pattern similar to Robertson Bay Group sample (4), with equally-dominant latest Neoproterozoic-Cambrian (25\%) and Mesoproterozoic (25\%) groups. Within the former, the youngest detrital zircon age component, $497 \pm 19 \mathrm{Ma}$, 
imposes a maximum, late Cambrian-Early Ordovician depositional age. These rocks clearly appear to be in the same family as the Robertson Bay Group and the Swanson Formation. Two individual zircons, $323 \pm 8$ and $352 \pm 14 \mathrm{Ma}$, appear spuriously young, perhaps resulting from partial $\mathrm{Pb}$ loss associated with incipient thermal metamorphism adjacent to the nearby Menhir Gabbro (Miocene). At Garden Cove, Campbell Island, the age patterns in schistose metasediments there (also Complex Point Formation) are different. The Rb-Sr metamorphic age, $526 \pm 18 \mathrm{Ma}$, and a youngest detrital zircon age component, $525 \pm 4 \mathrm{Ma}$ (Adams 2007), suggest a depositional age here in the range earliest Cambrian to early Middle Cambrian. The metamorphic basement on Campbell Island therefore seems to contain two separate units with two discrete metamorphic events. One is probably Ross-Delamerian type and the other is similar to that in the Robertson Bay Group and Swanson Formation in Antarctica and thus more related to the Lachlan Orogen in Australia.

In Westland, New Zealand, the Greenland Group sample locality 7 near Ross, continues the detrital zircon age trends observed in all the previous samples (1-6). The age patterns are similar to those reported by Ireland \& Gibson (1998). The latest Neoproterozoic-Early Ordovician age group is increased to $50 \%$, at the expense of the Mesoproterozoic group, which is now reduced to $20 \%$. Within the former, a youngest component age, $494 \pm 14 \mathrm{Ma}$, indicates a maximum, Early Ordovician depositional age, whilst $\mathrm{Rb}-\mathrm{Sr}$ metamorphic ages here, c. $440 \mathrm{Ma}$ (Adams 2004), provide a Late Ordovician minimum. A single, Early Ordovician fossil locality at Reefton $(60 \mathrm{~km}$ north-west) is accommodated within these maximum/minimum age constraints. This sample has a significant, and large (16\%), proportion of zircon ages in a 1300-2000 Ma range. Jongens et al. (2003) reported zircon age data from the Middle Cambrian, Junction Formation and Balloon Melange in the adjacent Takaka Terrane with prominent age groups at $520-530 \mathrm{Ma}$ and 900-1100 Ma.

\section{Discussion of zircon sources: contemporary arcs and continental hinterland}

\section{The pattern of detrital zircon components}

The significant detrital zircon age components for samples (1-8) are compiled in Fig. 3. In the absence of good stratigraphic age control for most of these, the component age data have to be stacked on the vertical axis in order of maximum stratigraphic age, as constrained by the age of the youngest, statistically-significant zircon component. In active-margin depositional settings that have extensive contemporaneous volcanism and good biostratigraphical age control, this youngest age component is frequently observed to coincide with the depositional age. In contrast, in depositional settings at a passive continental margin, there is not necessarily any correlation between the depositional age and that of the youngest detrital zircons. Both types may be represented here. The Berg Group and the Priestley Formation may thus record sedimentary basins developed at an inactive continental margin, subsequently incorporated into a more active Ross margin magmatic arc environment. In contrast, the Bowers Terrane sediments would represent intra-arc to back-arc deposition, whilst those of the Robertson Bay Group, Swanson Formation and Greenland Group would represent sedimentation in either a back-arc basin or a marginal marine basin related to a younger, retreating subduction system (Foster et al. 2005). These latter areas would also appear to overlap with the development of the Ordovician Macquarie Arc in southeast Australia (Fergusson 2009). The $\mathrm{Rb}-\mathrm{Sr}$ and $\mathrm{K}-\mathrm{Ar}$ metamorphic age data generally support the stratigraphic ordering, in that the Priestley Formation, Berg Group and part of the Complex Point Formation show Cambrian metamorphism (Ross-Delamerian), whilst the Swanson Formation, the younger part of the Complex Point Formation, Robertson Bay Group and Greenland Group all show Late Ordovician-early Silurian metamorphism.

Figure 3 shows two major, broad age groupings: firstly, a collection of significant and enduring zircon sources in a late Mesoproterozoic age range, 1000-1200 Ma, but particularly at c. $1050 \mathrm{Ma}$ (Group 1) and secondly, a diachronous group, in a broad late Neoproterozoic-Cambrian age range (500-600 Ma) (Group 2). The younger group has components mainly in the range $540-600 \mathrm{Ma}$ in the older samples (1-3), and 495-580 Ma in the younger samples (4-7). However, zircon components occur persistently at c. 525,550 and $595 \mathrm{Ma}$, which probably indicate a degree of zircon reworking, either by sediment recycling or via inheritance as xenocrysts in younger magmatic bodies. It should be noted here that the largest component (as \% of total) is frequently not the youngest, but commonly up to 30-50 million years older. This pattern presumably reflects the immediate but short-lived availability (at the million year scale) of local, superficial volcanic sources, in contrast to the delayed but long-lived exhumation and erosion of their more voluminous plutonic equivalents.

Group 1 zircons were supplied, throughout late Neoproterozoic-Early Ordovician times (c. 80 million years), without much variation, from a slowly-exhumed, late Mesoproterozoic region. A continental hinterland is suggested here, similar to that indicated by Goodge et al. (2002, 2004), which would include more scattered zircon contributions from minor, and much older cratonic sources, $>2000 \mathrm{Ma}$.

Group 2 zircons indicate the increasing dominance of sources within an extensive igneous province evolving from latest Neoproterozoic-Early Ordovician time, and which gradually overwhelmed zircons from Meso- and Palaeoproterozoic and Archean sources. The degree of diachronism within this group suggests continuous magmatic 
activity but this does not necessarily indicate the same tectonic environment, a feature seen in several active margins.

\section{Provenance of late Neoproterozoic to Early Ordovician sediments in East Gondwana}

In general terms, the zircon provenance patterns of the present study confirm the conclusions of Ireland et al. (1998) and Fergusson \& Fanning (2002) from similar studies mostly in eastern Australia, namely that detrital zircon patterns in these late Neoproterozoic-early Palaeozoic sediments reflect sediment sources that are developed from evolving plutonic/metamorphic complexes in the Ross-Delamerian Fold Belt. Individual zircon assemblages may of course be composite, with mixtures of primary and secondary sources, made available by tectonic events that are only distantly related. Possible sources of zircons that need to be considered include: footwall uplifts related to the development of passive margins or rifts, volcanic rocks related to active subduction, volcanic rocks related to post-orogenic relaxation and syn- and post tectonic granites. The extensive Cambrian-Ordovician granitoid complexes, especially in the Wilson Terrane in northern Victoria Land, and the Dry Valleys region of south Victoria Land, would certainly contribute voluminous and enduring sediments of appropriate composition to younger Palaeozoic sediments. Their country rocks, most probably late Neoproterozoic, would have also contributed a large proportion of inherited Precambrian zircons. Some Cambrian acidic volcanic complexes in northern Victoria Land and Tasmania would also be potential primary zircon sources, as well as the post-tectonic volcanic rocks of the latter. Primary igneous sources in the late Neoproterozoic are very rare. Older granitoids in the Delamerian of South Australia (Ireland et al. 1998) are the only candidates of some extent and appropriate composition. Thus, the widespread occurrence of 500-700 Ma inherited zircons in the great majority of Palaeozoic sedimentary rocks in East Gondwana naturally raises the speculation that an extensive primary source lies somewhere relatively close, but hidden under the Antarctic ice (Goodge et al. 2002, 2004, Veevers et al. 2006).

The location of Tasmania in the Ross-Delamerian Orogen is enigmatic. Tasmania is placed close to northern Victoria Land and the Ross Sea region in most continental reconstructions but recent U-Pb detrital zircon and metamorphic monazite age data (Berry et al. 2007) are difficult to reconcile with the patterns from Antarctica, Zealandia or the Australian mainland. Berry et al. (2008) made comparisons of detrital zircon patterns with those of south-west Laurentia and suggested possible affinities. Further research has suggested Antarctic affinities for Precambrian sandstones in Tasmania (Berry et al. 2008). This is based upon detrital age patterns similar to those of the clastic assemblages of the Beardmore Group
(Goodge et al. 2002, 2004). If, as is suggested by Berry et al. (2008), the Tasmania rocks originate in a peri-Antarctic location with sources similar to those of the inboard parts of the Beardmore Group, then the contrast with the outboard Beardmore Group (Goodge et al. 2004) implies separation from Antarctica by mid-Neoproterozoic (c. $750 \mathrm{Ma}$ ) time. Tasmania was strongly affected by early Ross-Delamerian deformations at 515-510 Ma, but isolated from Antarctica during the younger (500-495 Ma) phases. Subsequently, a close relationship between Tasmania and mainland Australia from late Cambrian times is more likely (Cayley 2011). It is clear, however, that the West Tasmania Terrane was not contributing sediments to the major Ordovician basins there, such as those of the Mathinna Group.

Some proposed Rodinia supercontinent reconstructions e.g. SWEAT, AUSMEX models, are dependent upon matching of extremely rare (or speculative) primary magmatic sources of late Mesoproterozoic ('Grenvilleage'), c. 1050-1150 Ma, rocks in East Gondwana, with equally rare contemporaries in adjacent parts of their proposed Laurentian neighbours (Goodge et al. 2004, Fioretti et al. 2005, Berry et al. 2008). It seems highly significant however, that despite the widespread occurrence of detrital zircons of this age in both sedimentary rocks, and as inherited zircons in plutonic rocks, the only possible sources of this age is in central Australia (Fergusson et al. 2007). This raises the possibility that complexes of similar age might occur under the Antarctic ice cap, a proposition supported by abundant detrital zircons, in the range 950-1300 Ma, found in the Skelton Group, of southern Victoria Land, Antarctica (Wysoczanski \& Allibone 2004). Similar age components also occur in the Beardmore Group datasets (Goodge et al. 2002, 2004). The dominance of the peaks might support a relatively local source.

Despite the new data from Antarctica, a completely compelling identification for the source of the abundant 1000-1300 Ma zircons present in this massive chain of Palaeozoic sedimentary basins spread across a region $>4000 \mathrm{~km}$ long, and $>1000 \mathrm{~km}$ wide, and with successions $>5 \mathrm{~km}$ depth, remains elusive. A possible alternative solution is presented by Li \& Evans (2011) in a partial Rodinia configuration that places South China in proximity to eastern Australia and East Antarctica. In this position, it may have provided sediment (and zircon) sources from the Mesoproterozoic and Neoproterozoic metamorphic complexes and magmatic arcs that surround its Palaeoproterozoic-Archean core.

\section{Conclusions}

We conclude that:

- Neoproterozoic and early Palaeozoic sedimentary rocks in this region have major components at c. 525, 550 and $595 \mathrm{Ma}$. 
- These ages are 40-80 million years older than their depositional age.

- Small younger zircon components are coincident with depositional ages and relate to contemporaneous volcanic sources.

- Zircons from older Ross-Delamerian plutonic equivalents become more important in the Ordovician.

- Late Mesoproterozoic age components at 1030 and 1070 Ma probably originate from sources in the interior of Gondwana whose exact location is unknown.

\section{Acknowledgements}

The samples used in this study were drawn from extensive collections by CJA and JDB as part of New Zealand (NZARP), American (USARP) and German (GANOVEX) Antarctic expeditions. The leaders and geologist colleagues of those expeditions are thanked for their advice and assistance. The constructive comments of the reviewers are also gratefully acknowledged.

\section{Supplemental material}

Two supplemental tables will be found at http://dx.doi.org/ $10.1017 / \mathrm{S} 0954102013000461$.

\section{References}

Adams, C.J. 1996. Geochronological evolution of the western margin of northern Victoria Land: $\mathrm{Rb}-\mathrm{Sr}$ and $\mathrm{K}-\mathrm{Ar}$ dating of the Berg Group and Berg/Archangel Granites. Geologisches Jahrbuch, B89, 179-184.

Adams, C.J. 1997. Initial strontium isotope signatures of Late Precambrian-early Paleozoic metasediments from northern Victoria Land terranes, West Antarctica. In Ricci, C.A. ed. The Antarctic region: geological evolution and processes. Siena: Terra Antarctic Publication, 227-236.

ADAms, C.J. 2004. Rb-Sr age and strontium isotope characteristics of the Greenland Group, Buller Terrane, New Zealand, and correlations at the East Gondwanaland margin. New Zealand Journal of Geology and Geophysics, 47, 189-200.

Adams, C.J. 2007. Paleozoic terranes at the Pacific Ocean margin of Zealandia. Gondwana Research, 13, 250-258.

Adams, C.J. \& Kreuzer, H. 1984. Potassium-argon age studies of slates and phyllites from the Bowers and Robertson Bay terranes, north Victoria Land, Antarctica. Geologisches Jahrbuch, B6, 265-288.

Berry, R.F., Steele, D.A. \& Meffre, S. 2008. Proterozoic metamorphism in Tasmania: implications for tectonic reconstructions. Precambrian Research, 166, 387-396.

Berry, R.F., Chmielowski, R.M., Steele, D.A. \& Mefrre, S. 2007. Chemical U-Th- $\mathrm{Pb}$ monazite dating of the Cambrian Tyennan Orogeny, Tasmania. Australian Journal of Earth Sciences, 54, 757-771.

Bradshaw, J.D. 2007. The Ross Orogen and the Lachlan Fold Belt in Marie Byrd Land, northern Victoria Land and New Zealand: implications for the tectonic setting of the Lachlan Fold Belt in Antarctica. In Cooper, A.K., Raymond, C.R. et al., eds. Antarctica: a keystone in a changing world. Online Proceedings of the 10th International Symposium on Antarctic Earth Sciences. USGS Open-File Report 2007-1047, Short Research Paper 059.
Bradshaw, J.D., Andrews, P.B. \& Field, B.D. 1983. Swanson Formation and related rocks of Marie Byrd Land and a comparison with the Robertson Bay Group of northern Victoria Land. In OlIVER, R.L., JAMES, P.R. \& J JGO, J.B., eds. Antarctic earth science. Canberra: Australian Academy of Science, 176-189.

Bradshaw, J.D., Gutjahr, M., Weaver, S.D. \& Bassett, K.N. 2009. Cambrian intra-oceanic arc accretion to the austral Gondwana margin: constraints on the location of proto-New Zealand. Australian Journal of Earth Sciences, 56, 587-594.

CAYLEY, R.A. 2011. Exotic crustal block accretion to the eastern Gondwanaland margin in the late Cambrian - Tasmania, the Selwyn Block, and implications for the Cambrian-Silurian evolution of the Ross, Delamerian and Lachlan orogens. Gondwana Research, 19, 628-649.

Cooper, R.A. 1974. Age of the Greenland and Waiuta groups, South Island, New Zealand (Note). New Zealand Journal of Geology and Geophysics, 17, 955-962.

Cooper, R.A. 1989. Early Paleozoic terranes of New Zealand. Journal of the Royal Society of New Zealand, 19, 73-112.

Dallmeyer, R.D. \& WRight, T.O. 1992. Diachronous cleavage development in the Robertson Bay Terrane, northern Victoria Land, Antarctica: tectonic implications. Tectonics, 11, 437-448.

Fergusson, C.L. 2009. Tectonic evolution of the Ordovician Macquarie Arc, central New South Wales: arguments for subduction polarity and anti-clockwise rotation. Australian Journal of Earth Sciences, 56, 179-193.

Fergusson, C.L. \& Fanning, C.M. 2002. Late Ordovician stratigraphy, zircon provenance and tectonics, Lachlan Fold Belt, southeastern Australia. Australian Journal of Earth Sciences, 49, 423-436.

Fergusson, C.L., Henderson, R.A., Fanning, C.M. \& Withnall, I.W. 2007. Detrital zircon ages in Neoproterozoic to Ordovician siliciclastic rocks, northeastern Australia: implications for the tectonic history of the east Gondwana margin. Journal of the Geological Society, 164, 215-225.

Fioretti, A.M., Black, L.P., Foden, J. \& Visona, D. 2005. Grenville age magmatism at the South Tasman Rise: a new piercing point for the reconstruction of Rodinia. Geology, 33, 769-772.

Foster, D.A., Gray, D.R. \& Spaggiari, C. 2005. Timing of subduction and exhumation along the Cambrian East Gondwana margin and the formation of Paleozoic back-arc basins. Bulletin of the Geological Society of America, 117, 105-116.

GLen, R.A. 2005. The Tasmanides of eastern Australia. Special Publication of the Geological Society of London, No. 246, 257-273.

Goodge, J.W., Williams, I.S. \& Myrow, P. 2004. Provenance of Neoproterozoic and lower Paleozoic siliciclastic rocks of the central Ross Orogen, Antarctica: detrital record of rift-, passive-, and activemargin sedimentation. Geological Society of America Bulletin, 116, $1253-1279$

Goodge, J.W., Myrow, P., Williams, I.S. \& Bowring, S.A. 2002. Age and provenance of the Beardmore Group, Antarctica: constraints on Rodinia supercontinental breakup. Journal of Geology, 110, 393-406.

Henjes-Kunst, F. \& Schussler, U. 2003. Metasedimentary units of the Cambro-Ordovician Ross Orogen in northern Victoria Land and Oates Land: implications for their provenance and geotectonic setting from geochemical and Nd-Sr isotope data. Terra Antarctica, 10, 103-128.

IrELAND, T.R. \& GiBson, G.M. 1998. SHRIMP monazite and zircon geochronology of high-grade metamorphism in New Zealand. Metamorphic Geology, 16, 149-167.

Ireland, T.R., Flöttmann, T., Fanning, C.M., Gibson, G.M. \& Preiss, W.V. 1998. Development of the early Palaeozoic Pacific margin of Gondwana from detrital-zircon ages across the Delamerian Orogen. Geology, 26, 243-246.

Jongens, R., Bradshaw, J.D. \& Fowler, A. 2003. The Balloon Melange, northwest Nelson: origin, structure, and emplacement. New Zealand Journal of Geology and Geophysics, 46, 437-448.

Li, Z.X. \& Evans, D.A.D. 2011. Late Neoproterozoic 40 degree intraplate rotation within Australia allows for a tighter-fitting and longer-lasting Rodinia. Geology, 39, 39-42. 
Pankhurst, R.J., Weaver, S.D., Bradshaw, J.D., Storey, B.C. \& Ireland, T.R. 1998. Geochronology and geochemistry of pre-Jurassic superterranes in Marie Byrd Land, Antarctica. Journal of Geophysical Research, 103, 2529-2547.

Roser, B.P., CoOper, R.A., NAthan, S. \& Tulloch, A.J. 1996. Reconnaisance sandstone geochemistry, provenance and tectonic setting of the lower Paleozoic terranes of the West Coast and Nelson, New Zealand. New Zealand Journal of Geology and Geophysics, 39, 1-16.

Sutherland, R. 1999. Basement geology and tectonic development of the greater New Zealand region: an interpretation from regional magnetic data. Tectonophysics, 308, 314-362.
Stump, E. 1995. The Ross Orogen of the Transantarctic Mountains. Cambridge: Cambridge University Press, 284 pp.

Veevers, J.J., Belousova, E.A., SAeed, A., Sircombe, K., Cooper, A.F. \& ReAD, S. 2006. Pan-Gondwanaland detrital zircons from Australia analysed for $\mathrm{Hf}$ isotopes and trace elements reflect an ice-covered Antarctic provenance of 700-500 Ma age, $\mathrm{T}_{\mathrm{DM}}$ of 2.0-1.0 Ga, and alkaline affinity. Earth Science Reviews, 76, 135-174.

Wysoczanski, R.J. \& Allibone, A.H. 2004. Age, correlation and provenance of the Neoproterozoic Skelton Group, Antarctica: Grenville age detritus on the margin of East Antarctica. Journal of Geology, 112, 401-416. 